\title{
Surgical Resection Technique for Convexity Meningiomas
}

\author{
Dr. Behzad Saberi* \\ MD, Medical Research, Esfahan, Iran
}

Submission: October 09, 2020; Published: October 28, 2020

*Corresponding author: Dr. Behzad Saberi, MD, Medical Research, Esfahan, Iran

\section{Mini Review}

Simpson grade "I" resection, is the goal in convexity meningiomas surgery. After craniotomy, by using intraoperative ultrasound, neuronavigation and visual inspection, the junction of the dura with the tumor is defined in a circumferential direction. Dural incision is made at least in one centimeter distance from the tumor in a circumference manner around the tumor. Bipolar cautery is used to the dural attachment center after tumor encircling. This cause the cut margins to be turned outwardly and cause the arachnoid margin to be obviously visualized [1].

To expose the intracranial surface of the tumor, the dural attachment may be removed. Then tumor separation along such arachnoid planes is done. To avoid cortical tissue direct manipulation and to maintain the dissected planes, cottonoid patties will be placed between the brain and the tumor, into the arachnoid cleft. Small tumors may be completely removed by using this method $[2,3]$.

Central debulking for large tumors will be done to achieve some goals:

i. It allows extracapsular differentiating between vessels of passage and feeding vessels, which would be of importance in removing the tumors which are located near the sylvian fissure,

ii. It allows retraction on the tumor capsule into the tumor and iii. It allows minimal disruption of the underlying brain tissue by exact identification, cautery and transection of the pial collateral feeding vessels.

Ultrasonic aspirator is used for central debulking. Loop cautery device can be used for central debulking of the fibrous and very much calcified tumors. By using hemostatic agents like thrombin-soaked gelfoam, most of the intratumoral bleedings can be controlled. By avoiding breaching the capsule during internal debulking process and making alternative internal debulking and then extracapsular dissecting, the tumor will be removed from its place [4].

It is important for the neurosurgeon to have enough knowledge about the surgical technique to remove convexity meningiomas and pay careful attention to the details to reach the best surgical results with lowest possible complications.

\section{References}

1. Morokoff AP, Zauberman J, Black PM (2008) Surgery for convexity meningiomas. Neurosurgery 63(3): 427-433; discussion 433-424.

2. Simpson D (1957) The recurrence of intracranial meningiomas after surgical treatment. J Neurol Neurosurg Psychiatry 20: 22-39.

3. Sanai N, Sughrue ME, Shangari G, Chung K, Berger MS, et al. (2010) Risk profile associated with convexity meningioma resection in the modern neurosurgical era. J Neurosurg 112(5): 913-919.

4. Giombini S, Solero CL, Morello G (1984) Late outcome of operations for supratentorial convexity meningiomas. Report on 207 cases. Surg Neurol 22(6): 588-594. 
(C) This work is licensed under Creative Commons Attribution 4.0 License
DOI:10.19080/CTOIJ.2020.17.555956
Your next submission with Juniper Publishers will reach you the below assets

- Quality Editorial service

- Swift Peer Review

- Reprints availability

- E-prints Service

- Manuscript Podcast for convenient understanding

- Global attainment for your research

- Manuscript accessibility in different formats

( Pdf, E-pub, Full Text, Audio)

- Unceasing customer service

Track the below URL for one-step submission https://juniperpublishers.com/online-submission.php 